\title{
Adipocytokines in obesity and metabolic disease
}

\author{
Haiming Cao \\ National Heart, Lung and Blood Institute, National Institutes of Health, Center for Molecular Medicine, \\ 10 Center Drive, Building 10, 8N109, MSC 1760, Bethesda, Maryland 20892, USA
}

Correspondence should be addressed to $\mathrm{H}$ Cao

Email

haiming.cao@nih.gov

\begin{abstract}
The current global obesity pandemic is the leading cause for the soaring rates of metabolic diseases, especially diabetes, cardiovascular disease, hypertension, and non-alcoholic hepatosteatosis. Efforts devoted to find cures for obesity and associated disorders in the past two decades have prompted intensive interest in adipocyte biology, and have led to major advances in the mechanistic understanding of adipose tissue as an essential endocrine organ. Adipose tissue secretes an array of hormones (adipokines) that signal key organs to maintain metabolic homeostasis, and their dysfunction has been causally linked to a wide range of metabolic diseases. In addition, obesity induces production of inflammatory cytokines (often referred to together with adipokines as adipocytokines) and infiltration of immune cells into adipose tissue, which creates a state of chronic low-grade inflammation. Metabolic inflammation has been increasingly recognized as a unifying mechanism linking obesity to a broad spectrum of pathological conditions. This review focuses on classic examples of adipocytokines that have helped to form the basis of the endocrine and inflammatory roles of adipose tissue, and it also details a few newly characterized adipocytokines that provide fresh insights into adipose biology. Studies of adipocytokines in clinical settings and their therapeutic potential are also discussed.
\end{abstract}

\author{
Key Words \\ - adipocytokine \\ - obesity \\ - adipokine \\ - metabolic inflammation \\ - adipocyte
}

\section{Introduction}

In the past two decades, the world has seen a sustained increase in obesity, and the levels of overweight and obese persons worldwide have reached epidemic proportions (Finucane et al. 2011). It is well established that obesity induces all major metabolic disorders, especially diabetes, cardiovascular disease, hypertension, and fatty liver disease (Eckel et al. 2005). Mounting evidence also links obesity to a growing list of debilitating disorders including neurodegenerative disease, airway disorders, and cancer, all of which contribute to the staggering morbidity and mortality associated with obesity. Aimed at developing effective therapies for obesity and its associated disorders, scientists worldwide have intensified their efforts to elucidate the pathophysiological mechanisms by which obesity induces or amplifies its major adverse consequences. The concept of an adipocytokine was developed in this process and dysfunction of adipocytokine pathways has been recognized as a key etiological factor of obesity-induced disorders. Furthermore, the rational manipulation of adipocytokines is becoming a promising avenue of therapy for obesity and associated metabolic abnormalities.

\section{Endocrine function of adipose tissue and adipokines}

Obesity is the expansion of white adipose tissue (WAT), the most effective lipid storage organ in the body. In obese 
subjects, white adipocytes in WAT have increased release of free fatty acids (FFAs) through lipolysis process leading to elevated serum fatty acid levels. This overflow of lipids from obese adipose depots has been considered a key reason for obesity-associated insulin resistance and hepatosteatosis for several decades (Randle et al. 1963, Samuel et al. 2010). But fatty acids in this setting have often been considered as a whole, and studies examining the distinct impact of individual lipid species have provided intriguing insights into the specificities of adipose-secreted lipids (Cao et al. 2008). In 1994, leptin was identified as an adipose-secreted hormone (adipokine) that exhibits potent anorexic effects, and this finding redefined WAT as an endocrine organ (Zhang et al. 1994). In the following two decades, several more adipokines were identified as critical regulators of systemic lipid and glucose homeostasis, and the list continues to grow (Fig. 1). Adipokines mediate the crosstalk between adipose tissue and other key metabolic organs, especially the liver, muscle, and pancreas, as well as the CNS (Rosen \& Spiegelman 2006). Consistent with this notion, dysfunctions in adipokine pathways often result in impaired organ communications and metabolic abnormalities in multiple tissues thereby constituting a critical pathological component in the development of metabolic disease (Trujillo \& Scherer 2006).

\section{Metabolic inflammation and adipocytokines}

Hotamisligil et al. (1993) showed that adipose tissue in obese mice secretes tumor necrosis factor $\alpha$ (TNF $\alpha$ ), a proinflammatory cytokine typically produced by immune cells, and also demonstrated that adipocyte-derived TNF $\alpha$ plays a direct role in obesity-induced insulin resistance. This was the first functional link between obesity and inflammation, and over the years it has evolved into the concept of metabolic inflammation (Fig. 1), which has been widely accepted as an important mechanistic connection between obesity and its complications (Hotamisligil 2006). After $\mathrm{TNF} \alpha$, it was demonstrated that adipose tissue produces an array of cytokines and chemokines such as IL6 and MCP1, which either positively or negatively regulate systemic glucose and lipid metabolism. Interestingly some adipokines also exhibit features

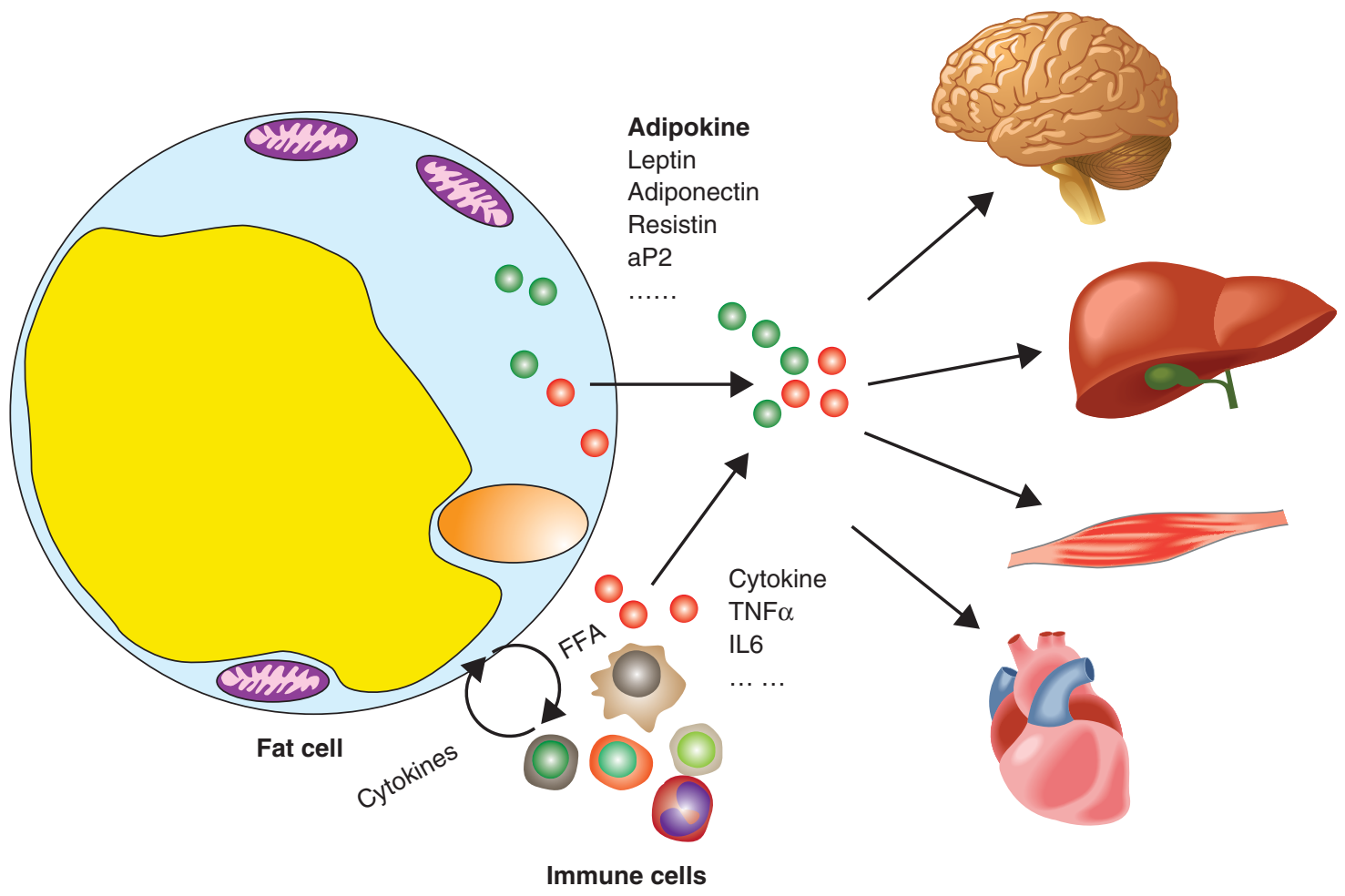

\section{Figure 1}

Adipocytokines and metabolic inflammation in adipose tissue. Adipocytokines derived from adipose tissue are the results of intertwined interaction between adipocytes and immune cells that infiltrate adipose tissue. Adipocytokines mediate crosstalk among different cell populations within adipose tissue and also travel to remote organs to regulate systemic energy metabolism. The level and action of adipocytokines are often altered in obese subjects, which contribute to obesity-induced disorders. http://joe.endocrinology-journals.org DOI: 10.1530/JOE-13-0339
() 2014 Society for Endocrinology Printed in Great Britain
Published by Bioscientifica Ltd 
of cytokines or regulate inflammatory responses, and so these two groups of adipose-derived factors are often collectively referred to as 'adipocytokines' (Fig. 1). In 2003, two studies simultaneously reported that obesity induces macrophage infiltration of adipose tissue in both mice and humans (Weisberg et al. 2003, Xu et al. 2003b), which not only provided an explanation for the source of adiposederived cytokines but also demonstrated for the first time the close juxtaposition between immune and metabolic cells in a metabolic organ. Adipose-resident macrophages are classified into two very distinct subtypes, M1, or classically activated, and M2, or alternatively activated. M1 macrophages secrete proinflammatory cytokines, such as TNF $\alpha$ and IL6, produce iNOS and reactive oxygen species (ROS), and cause insulin resistance. M2 macrophages produce IL10 and IL1 receptor antagonists and arginase- 1 and have been implicated in tissue remodeling (Gordon 2003). Obesity causes a shift of macrophage subtypes in adipose tissue from M2 to M1 activation, leading to increased levels of proinflammatory cytokines and ROS, which induce insulin resistance (Lumeng et al. 2007). Meanwhile, the loss of certain beneficial effects associated with M2 macrophages might also contribute to the metabolic deterioration in obesity. For examples, M2 macrophages produce catecholamines that sustain adaptive thermogenesis (Nguyen et al. 2011), and lipolysis during fasting recruits macrophages that buffer local lipid increase and protect adipose function (Kosteli et al. 2010). Following macrophages, nearly every major type of immune cell has been identified in adipose tissue in recent years (Feuerer et al. 2009, Liu et al. 2009, Winer et al. 2009, Wu et al. 2011) and is actively involved in the endocrine function of adipose tissue in systemic metabolic regulation. Furthermore, the close physical and signaling interactions between immune and metabolic cells also exist in all major metabolic organs of obese subjects especially the liver, muscle, and pancreas, indicating that metabolic inflammation is a universal feature and a pathological basis for obesity-induced metabolic dysfunction.

There are a number of potential underlying causes for obesity-induced adipose inflammation. Adipose tissue expansion in the development of obesity can cause hypoxia which induce compensatory angiogenesis. Macrophages are recruited to the site to facilitate the vascularization process (Pang et al. 2008). Similar function of immune cells was also demonstrated in other metabolic tissues such as liver where Kupffer cell-secreted TNF $\alpha$ and IL6 in mouse liver are required for efficient liver regeneration (Abshagen et al. 2007). Infiltrated macrophages in adipose tissues have also been proposed to be a mechanism to remove apoptotic cells (Cinti et al. 2005, Strissel et al. 2007). In addition, endotoxemia associated with altered gut permeability and obesity might potentiate adipose inflammation (Cani et al. 2007). Although accumulating evidence supports an overall negative effect of adipose inflammation on energy metabolism, it should bear in mind that not all metabolic inflammation is detrimental to metabolic homeostasis. Inflammation associated with adipose expansion or repair might be necessary for the body to adapt to the excess energy and maintain metabolic homeostasis (Ye \& McGuinness 2013). In the same vein, certain cytokines stimulate energy expenditure and reduce food intake which might help to curtail obesity (Ye \& Keller 2010). Therefore, the metabolic outcomes of adipose inflammation should always be considered in the context of their physiological underpinnings, and more studies are needed to fully understand the extent and mechanism of beneficial inflammatory responses associated with different stages of obesity.

\section{Key adipocytokines in metabolic regulation and obesity-induced metabolic disorders}

\section{Leptin}

Leptin was identified through positional cloning by Zhang et al. (1994), and is one of most potent adipocytokines in metabolic regulation. Leptin regulates body weight by signaling nutritional status to other organs especially the hypothalamus, which produces neuropeptides and neurotransmitters that modulate food intake and energy expenditure (Friedman \& Halaas 1998). Leptin also has anti-diabetic effects independent of its regulation of body weight and energy intake (Kamohara et al. 1997). Leptin regulates hepatic lipogenesis by suppressing the expression of key enzymes in the fatty acid synthesis pathway (Cohen et al. 2002) and enhances muscle fatty acid oxidation by activating a critical energy sensor AMPK (Minokoshi et al. 2002).

At the signaling level, leptin activates the leptin receptor, which has multiple splicing isoforms, although the long isoform mediates all known leptin actions (Lee et al. 1996). There are multiple pathways downstream of the leptin receptor, each of which mediates different aspects of leptin activities (St-Pierre \& Tremblay 2012). The main signaling branch of leptin is the JAK-STAT pathway, which regulates expression of anorexic neuropeptides (Baumann et al. 1996). This pathway is essential

Published by Bioscientifica Ltd 
for leptin regulation of energy balance but not its effects on reproduction (Bates et al. 2003). The anti-diabetic effect of leptin is mediated by centrally activating the phosphatidylinositol-3-kinase (PI3K)/AKT pathway that stimulates insulin sensitivity in the peripheral tissues (Morton et al. 2005).

In light of the significance of metabolic inflammation in the pathogenesis of metabolic disease, it is worth mentioning that leptin bears striking similarity to cytokines and modulates immune responses (De Rosa et al. 2007). Leptin is structurally similar to Class I helical cytokines and shares the same JAK-STAT pathway downstream of its receptor. Leptin expression can be induced by endotoxin or cytokine TNF $\alpha$ (Grunfeld et al. 1996). Conversely, leptin increases thymic secretion of acutephase reactants and TNF $\alpha$ and promotes T helper 1 cell differentiation (La Cava \& Matarese 2004). Leptin acts on $\mathrm{T}$ cell, macrophages, and other immune cells to stimulate the production of a wide spectrum of cytokines (La Cava \& Matarese 2004). In light of the role of several cytokines in enhancing energy expenditure and suppressing food intake (Ye \& Keller 2010), this proinflammatory action of leptin might contribute to its overall effects in body weight regulation. Interestingly, inflammation induced by metabolic stress also negatively regulates leptin signaling in a manner similar to insulin receptor signaling (Zhang et al. 2008). In addition, leptin has been implicated in a number of immune dysfunctions. For examples, leptin is able to reverse starvation-induced immunosuppression (Lord et al. 1998) and has been proposed to be a metabolic link to multiple sclerosis (Matarese et al. 2010).

Despite the thorough understanding of leptin's actions and numerous attempts to target leptin for obesity and metabolic disorders (Coppari \& Bjorbaek 2012), leptin's clinical applications have been very limited. Leptin is used to treat genetically obese subjects carrying leptin mutations, but such mutations are extremely rare (Farooqi et al. 1999). Leptin is largely ineffective for treating regular obese patients due to leptin resistance caused by hyperleptinemia, and leptin administration into these individuals does not generate anorexic effects (Heymsfield et al. 1999). Leptin is successfully used to treat insulin resistance and hepatic steatosis in patients with congenital severe lipodystrophy who have very low levels of circulating leptin (Oral et al. 2002, Petersen et al. 2002). With increased mechanistic understanding of leptin resistance (St-Pierre \& Tremblay 2012), it is still possible that approaches to enhance leptin sensitivity could help to revive some of stalled attempts to target leptin for antiobesity and anti-diabetic therapies.

\section{Adiponectin}

Several research groups identified adiponectin almost simultaneously as an abundantly secreted adipokine (Scherer et al. 1995, Hu et al. 1996, Maeda et al. 1996, Nakano et al. 1996). Recombinant adiponectin can enhance insulin action and partially reverse insulin resistance in obese mice (Berg et al. 2001, Yamauchi et al. 2001). Consistently, multiple groups have reported that adiponectin-deficient mice develop insulin resistance associated with high level of TNF $\alpha$ in adipose tissue and reduced responsiveness to PPAR $\lambda$ (Maeda et al. 2002, Nawrocki et al. 2006), although an independently generated adiponectin knockout mouse line has no change in insulin sensitivity (Ma et al. 2002). Adiponectin has also been reported to have antiatherogenic effects (Funahashi et al. 1999, Ouchi et al. 1999). In addition, adiponectin exhibits cardioprotective activity in ischemic heart disease through AMPK and cyclooxygenase 2 pathways (Shibata et al. 2005).

Adiponectin signaling is mediated by two adiponectin receptors, adipoR1 and adipoR2 (Yamauchi et al. 2003). AdipoR1 is ubiquitously expressed whereas adipoR2 is enriched in the liver tissue. Knockout of adipoR1 and adipoR2 abrogates adiponectin binding and causes lipid accumulation, inflammation, and insulin resistance (Yamauchi et al. 2007). Activation of adipoR1 in the liver and muscle tissues increases AMPK activity, which mediate the insulin sensitizing effect of adiponectin and also enhances fatty acid oxidation (Yamauchi et al. 2002). The adipoR2 pathway in the liver increases PPAR $\alpha$ and expression of its target genes, which also results in increased fatty acid oxidation (Yamauchi et al. 2007). Recently, it has been reported that a variety of downstream effects of the adiponectin receptor are mediated by ceramidase activity associated with adipoR1 and adipoR2 (Holland et al. 2011). Adiponectin also has antiinflammatory effects that contribute to its protective role against metabolic stress in obesity. Adiponectin suppresses $\mathrm{TNF} \alpha$ production in obese mice (Xu et al. 2003a), and adiponectin-deficient mice have high levels of TNF $\alpha$ in adipose tissue (Maeda et al. 2002). Low levels of plasma adiponectin are associated with C-reactive protein in humans (Ouchi et al. 2003). Adiponectin enhances the clearance of apoptotic cells by facilitating their opsonization and uptake by macrophages (Takemura et al. 2007). Some of the anti-atherogenic effects of adiponectin are also mediated by its role in the suppression of inflammatory responses. Adiponectin inhibits nuclear factor- $\mathrm{\kappa} B$ $(\mathrm{NF \kappa B})$ activity and its downstream adhesion molecules

Published by Bioscientifica Ltd

Downloaded from Bioscientifica.com at $04 / 26 / 2023$ 02:15:36AM via free access 
leading to reduced monocyte adhesion to endothelial cells (Ouchi et al. 1999, Okamoto et al. 2002). In addition, adiponectin confers vascular-protective activities by suppressing the apoptosis of endothelial cell (Kobayashi et al. 2004).

Clinical observations support the idea that plasma adiponectin levels are associated with obesity-induced disorders, especially diabetes. Plasma adiponectin levels are decreased in type 2 diabetic patients, and higher adiponectin levels are associated with low risk of diabetes (Li et al. 2009). Adiponectin levels are also negatively associated with adiposity and fasting glucose (Ryo et al. 2004). A multi-ethnic meta-analysis of a large cohort also demonstrated that numerous genetic loci associated with adiponectin levels influence risk of insulin resistance and type 2 diabetes (Dastani et al. 2012). Currently, several strategies to boost adiponectin levels or adiponectin receptor activities are being explored for the treatment of obesity-induced inflammation and insulin resistance (Yamauchi \& Kadowaki 2008).

\section{Tumor necrosis factor $\alpha$}

$\mathrm{TNF} \alpha$ was the first cytokine identified in the adipose tissue of obese mice, marking the start of the metabolic inflammation concept (Hotamisligil et al. 1993). The direct involvement of TNF $\alpha$ in obesity-induced insulin resistance was confirmed by observations that TNF $\alpha$ treatment interferes with insulin signaling and blocks insulin actions (Hotamisligil et al. 1994). Mice lacking the functions of TNF $\alpha$ or its receptors are protected from obesity-induced insulin resistance and hyperglycemia (Uysal et al. 1997, 1998). It was initially thought that adipose-derived TNF $\alpha$ was produced mainly by adipocytes, but the parallel trend of macrophage infiltration and TNF $\alpha$ expression in adipose tissue of obese mice suggests that a significant portion of the adipose TNF $\alpha$ pool might be derived from macrophages and other immune cells. Interesting, FFA strongly stimulates $\mathrm{TNF} \alpha$ production in macrophages (Nguyen et al. 2005) and in turn, TNF $\alpha$ stimulates lipolysis to increase fatty acid release from adipocytes (Wang et al. 2008). This FFA-cytokine cycle suggests that metabolic inflammation, once started, can use this self-perpetuating mechanism to further its inhibitory effects on insulin signaling and energy metabolism. In addition, $\mathrm{TNF} \alpha$ directly stimulates hepatic lipogenesis in vivo (Feingold \& Grunfeld 1987), and adipose-derived $\mathrm{TNF} \alpha$ is also a major mechanistic link between obesity and cancer (Park et al. 2010).
TNF $\alpha$ exerts its effects through two distinct receptors, p55 and p75, which further activate JNK1 and inhibit IкB kinase(IKK)/NFKB pathways (Baud \& Karin 2001). JNK1 can directly inhibit insulin signaling by phosphorylating insulin receptor substrate 1 (IRS1) on serine residues (Aguirre et al. 2002) and can also potentiate fatty acidinduced cytokine production (Nguyen et al. 2005). Consistent with these observations, JNK1 knockout mice are protected from obesity and insulin resistance (Hirosumi et al. 2002). IKK can also directly inhibit IRS1 function through serine phosphorylation in a manner similar to JNK1 (Gao et al. 2002) and also activate NFאB to produce inflammatory cytokines both in metabolic organs and myeloid cells. It has been demonstrated that systemic or selective inhibition of IKK in either hepatocytes or myeloid cells improves glucose metabolism in mice (Yuan et al. 2001, Arkan et al. 2005, Cai et al. 2005). TNFa also induces the expression of cytokine signaling 3 (SOCS3) suppressor, which inhibits insulin signaling by increasing ubiquitin-mediated IRS1 and IRS2 degradation (Emanuelli et al. 2001, Rui et al. 2002). Recently, a report has demonstrated that $\mathrm{TNF} \alpha$ increase leptin receptor expression, raising an interesting possibility that TNF $\alpha$ might enhance leptin action (Gan et al. 2012), although the physiological relevance of this connection needs to be confirmed in an in vivo setting.

Numerous studies in humans have demonstrated strong associations between circulating $\mathrm{TNF} \alpha$ and insulin resistance (Hivert et al. 2008) or other obesity-associated metabolic complications (Berg \& Scherer 2005). However, attempts to block TNF $\alpha$ function in patients have not yet produced consistent metabolic outcomes. For example, neutralization of TNF $\alpha$ with an engineered antibody did not improve insulin sensitivity in type 2 diabetes patients (Ofei et al. 1996), whereas blockade of TNF $\alpha$ in patients with rheumatoid arthritis or psoriasis indeed improved their insulin resistance (Gonzalez-Gay et al. 2006, Lo et al. 2007). Considering the wide spectrum of inflammatory cytokines that are elevated in obesity, targeting TNF $\alpha$ alone might not have sufficient efficacy to improve systemic metabolic responses and might need to be considered in the context of managing the overall metabolic inflammation.

\section{Resistin}

Resistin was initially identified in a screen for adipocyte genes that are suppressed by insulin-sensitizing drugs in rodents (Steppan et al. 2001). Depletion of circulating resistin by a neutralizing antibody improves insulin action

Published by Bioscientifica Ltd 
in obese mice, suggesting that resistin is an adipokine linking obesity to insulin resistance (Steppan et al. 2001). Subsequently, it was shown that resistin knockout mice on a high-fat diet have improved glucose metabolism mainly due to reduced glucose production in the liver (Banerjee et al. 2004). Resistin also increases the expressions of cytokines and adhesion molecules in murine vascular endothelial cells and contributes to atherogenesis (Burnett et al. 2005). Resistin circulates in two distinct assembly states, which exhibit differential activities in metabolic regulation (Patel et al. 2004). However, the relevance of resistin to human disease is complicated by the fact that rodent resistin is produced in adipocytes and human resistin is produced mostly in macrophages. Human and rodent resistin only shares 59\% identity at the amino acid level, which is relatively low compared with other hormones (Ghosh et al. 2003). But interestingly, human resistin, when expressed in mouse macrophages, also induces insulin resistance (Qatanani et al. 2009) suggesting that human and mouse resistin might have similar function despite their different sites of production.

In humans, experimental endotoxemia induced elevated resistin and produced an insulin-resistant state (Lehrke et al. 2004). Epidemiological studies have associated elevated circulating resistin with increased risk for type 2 diabetes, inflammatory markers, myocardial infarction, and atherosclerosis (Burnett et al. 2005, 2006, Reilly et al. 2005, Heidemann et al. 2008, Chen et al. 2009). These studies support the idea that resistin levels could serve as an informative marker for metabolic disease in humans, and it will be of great interest to determine the therapeutic potential of resistin inhibition in future studies.

\section{IL6}

IL6 is one of the major pro-inflammatory cytokines whose expression level increases in the adipose tissue of obese mice and patients, but its role in glucose metabolism has not been fully resolved. IL6 depletion in obese mice with a neutralizing antibody improves hepatic insulin action (Klover et al. 2005) while chronic infusion of IL6 causes insulin resistance in the liver of mice (Klover et al. 2003). Conversely, mice with targeted ablation of IL6 develop obesity and insulin resistance, which can be reversed by centrally delivered exogenous IL6 (Wallenius et al. 2002) suggesting that IL6 is required for the maintenance of whole-body glucose metabolism and metabolic homeostasis. An independently generated IL6-targeted mutation mouse line, however, does not develop obesity or insulin resistance and only exhibits elevated glucose level in a glucose tolerance test (Di Gregorio et al. 2004). In a mouse model with adipose-specific ablation of JNK1, increased secretion of IL6 was proposed to be the primary reason for systemic insulin resistance (Sabio et al. 2008). There are several potential explanations for the seemingly contradictory data regarding IL6 in insulin action and glucose metabolism. Effects of acute vs chronic treatments need to be differentiated and dose and site of action of IL6 need to be carefully considered. In addition, IL6 produced by different organs might also contribute to its complex effects on metabolic regulation.

During exercise, IL6 is mainly released from working skeletal muscle. IL6 release from contracting skeletal muscle might mediate the beneficial effects associated with exercise, including increased glucose uptake and fatty acid oxidation (Febbraio \& Pedersen 2002). It appears that activation of AMPK by IL6 mediates these effects (Al-Khalili et al. 2006). In addition, transgenically expressed human IL6 in mice increases leptin sensitivity and prevents diet-induced obesity (Sadagurski et al. 2010). However, the function of muscle-derived IL6 might also vary depending on its context. In a mouse model with muscle-specific disruption of PPAR $\lambda$ coactivator $1 \alpha$ (PGC1 $\alpha$ ), muscle-secreted IL6 causes impaired insulin production from pancreatic islets and glucose intolerance (Handschin et al. 2007).

In patient studies, increased serum IL6 correlates with obesity and insulin resistance (Vozarova et al. 2001, Bastard et al. 2002, Spranger et al. 2003). The IL6 174G > $\mathrm{C}$ single nucleotide polymorphism (SNP) is associated with insulin resistance and metabolic syndrome (Fernandez-Real et al. 2000, Stephens et al. 2007). However, the mechanism of action of IL6 in human metabolism needs to be further studied to understand the therapeutic potential of IL6, partly due to the fact that there is low similarity between human and mouse IL6, and thus information generated from mouse studies cannot be readily applied to humans. To add to the complexity of IL6 signaling in human metabolism, two reports showed that MAB against the IL6 receptor, Tocilizumab, either increases or has no effects on insulin sensitivity in patients with rheumatoid arthritis (Schultz et al. 2010, Ogata et al. 2011, Ye \& McGuinness 2013).

\section{Rbp4}

Rbp4 is a transport protein for retinol in systemic circulation, and is mainly produced by the liver but also expressed in white adipocytes. Rbp4 was first characterized as an adipokine based on the finding that Rbp4 is highly

Published by Bioscientifica Ltd 
secreted from adipose tissue of Glut4-deficient mice and contributes to insulin resistance in this mouse model (Yang et al. 2005). In humans, higher Rbp4 levels are also associated with insulin resistance in obese and diabetic subjects (Graham et al. 2006). In addition, a number of Rbp4 SNPs have been identified and several of them are associated with increased risk for type 2 diabetes (Kovacs et al. 2007, Munkhtulga et al. 2007). However, several reports failed to detect the association of Rbp4 with insulin resistance (von Eynatten et al. 2007, Promintzer et al. 2007, Yao-Borengasser et al. 2007), potentially due to shortcomings in the methodologies for quantifying Rbp4 levels (Kotnik et al. 2011). In general, clinical studies on children and adolescents have been more consistent in supporting a role for Rbp4 in obesity and insulin resistance, suggesting that $\mathrm{Rbp} 4$ might be more involved in the early stages of metabolic syndrome (Kotnik et al. 2011).

\section{Secreted frizzled-related protein 5}

Secreted frizzled-related protein 5 (Sfrp5) was recently identified as an anti-inflammatory adipocytokine (Ouchi et al. 2010). Sfrp5 is highly expressed in adipose tissue of lean mice but downregulated in obese mice. Targeted mutation of Sfrp5 in mice caused insulin resistance, glucose intolerance, and hepatosteatosis when the animals were fed a high-fat diet (Ouchi et al. 2010). Mechanistically, Sfrp5 activates JNK1 through noncanonical Wnt signaling to increase the levels of inflammatory cytokines and block insulin action (Ouchi et al. 2010). However, a second independently generated Sfrp5 mutation mouse line was reported to have different phenotypes, and accordingly the authors proposed a very different mechanism of actions for Sfrp5. In this study, Sfrp5-deficient mice were resistant to diet-induced obesity due to enhanced mitochondrial activities (Mori et al. 2012). Sfrp5 deficiency increased the expression of PGC1 and mitochondrial transcription factor A (Tfam), leading to increased mitochondrial biogenesis. Lack of Sfrp5 also stimulated mitochondrial respiration and gene expression through Wnt3a activity (Mori et al. 2012). The cause of these discrepancies is unclear. Human studies regarding Sfrp5 in metabolic disease have also given rise to conflicting data (Carstensen et al. 2013, Hu et al. 2013). Regardless, further studies about the function of Sfrp5 in metabolic regulation could provide important insights into adipose biology. Sfrp5 regulates multiple Wnt proteins that play a crucial role in adipogenesis (Cristancho \& Lazar 2011). Dissecting the Sfrp5/Wnt network in adipose tissue could also help to explain the autocrine/paracrine mechanism of metabolic inflammation, which is still poorly understood.

\section{aP2, a lipid-activated adipocytokine}

The identification of aP2 as a lipid-activated adipokine is a surprising and exciting finding considering it has been extensively studied for over two decades as an essential intracellular regulator of lipid metabolism and inflammation in metabolic disease. AP2 is a member of fatty acid-binding protein (FABP) family and was initially thought to be exclusively expressed in adipocytes. In fact, the aP2 promoter has been widely used to specially drive transgene expression in adipose tissue. AP2-deficient mice have normal adiposity and gain more weight than controls when fed with high-fat diet, but they were partially protected from obesity-induced insulin resistance (Hotamisligil et al. 1996). The mild effect of aP2 deficiency could be due to the upregulation of mal1, a related FABP (Maeda et al. 2005). Therefore, mice deficient in both FABPs were produced to study the full impact of adipose FABP deficiency. The double-knockout mice have reduced adiposity, enhanced insulin sensitivity, and reduced hepatosteatosis (Maeda et al. 2005). It appears that some of the beneficial effects of FABP deficiency are mediated by robust upregulation of the fatty acid species, palmitoleate (C16:1n7), in the adipose tissue and its secretion into circulation (Fig. 2). Palmitoleate enhances insulin action in the muscle and suppresses de novo lipogenesis in the liver (Cao et al. 2008).

Yet the molecular mechanism for the pronounced reduction in gluconeogenesis in FABP-deficient mice remained elusive until it was found that aP2 is in fact actively secreted from adipocytes to control liver glucose metabolism (Cao et al. 2013; Fig. 2). Secretion of aP2 from adipocytes is regulated by lipolysis, which might be the reason that circulating aP2 levels are markedly elevated in obesity. Recombinant aP2 stimulates hepatic glucose production whereas neutralization of secreted aP2 reduces glucose production and corrects the diabetic phenotype of obese mice (Cao et al. 2013).

aP2 is the first adipokine whose secretion is strongly regulated by lipolysis-released fatty acids, suggesting that aP2 might function as a lipid sensor in adipocytes and might also carry specific lipids in plasma to specific organs or cells. Therefore, like other well-studied adipocytokines, it is conceivable that secreted aP2 could potentially act on other key organs such as the CNS or heart to regulate other aspects of metabolic homeostasis (Fig. 2) and these

Published by Bioscientifica Ltd 


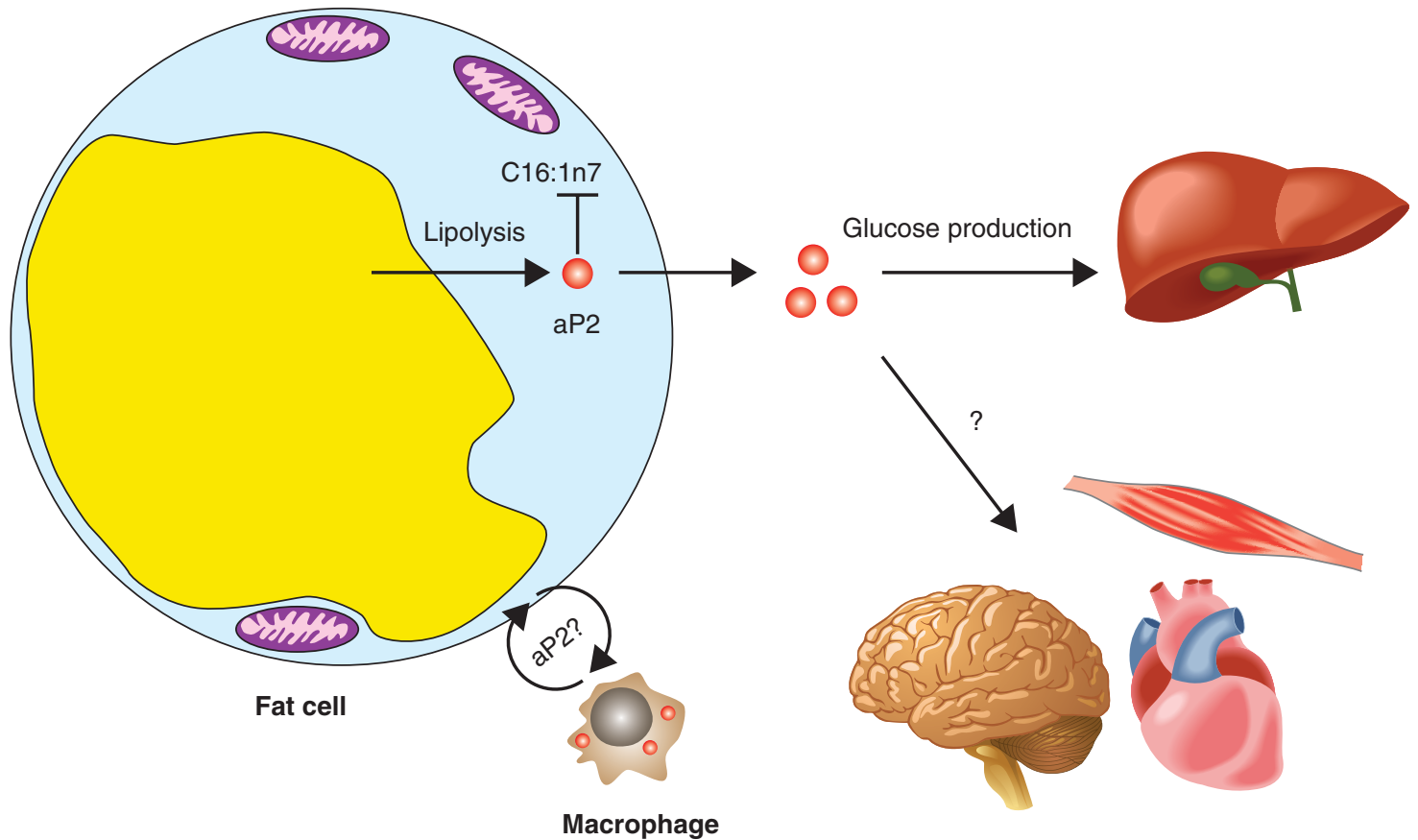

\section{Figure 2}

aP2 as a lipid-activated adipokine. aP2 is secreted from adipocytes through a process that is regulated by fasting and lipolysis. Circulating aP2 acts on liver tissue to stimulate the gluconeogenic program and enhance hepatic

questions need to be addressed in future studies. Another interesting question is whether secreted aP2 is also involved in metabolic inflammation. Despite long having been considered an adipocyte-specific protein, aP2 was found to be expressed in the macrophages (Makowski et al. 2001) and can be quickly induced by endotoxin (Kazemi et al. 2005). Mice with aP2 deficiency in macrophages are protected from atherosclerosis partly because of activated $\operatorname{PPAR} \gamma$ and reduced inflammatory responses (Makowski et al. 2005). The proinflammatory action of aP2 was also demonstrated in an asthma mouse model, in which aP2 deficiency protects mice from airway inflammation (Shum et al. 2006). It will be interesting to investigate whether aP2 is also secreted from macrophages and whether secreted aP2 regulates inflammatory responses in metabolic diseases (Fig. 2).

Accumulating evidence suggests that circulating aP2 is implicated in human metabolic syndrome. Plasma aP2 levels are closely associated with obesity and metabolic syndrome in cohorts of multiple ethnicities (Stejskal \& Karpisek 2006, Xu et al. 2006, Simon et al. 2009). In addition, circulating aP2 has also been linked to carotid atherosclerosis in humans (Yeung et al. 2007) and nonalcoholic fatty liver disease (NAFLD; Koh et al. 2009). In NAFLD patients, elevated plasma aP2 levels independently glucose production. Other potential functions of aP2 in local adipose-macrophage interaction and on other metabolic organs warrant further investigation.

predict inflammation and fibrosis (Milner et al. 2009). Neutralizing secreted aP2 robustly improves glucose metabolism (Cao et al. 2013), indicating that plasma aP2 could constitute a potential therapeutic target for diabetes, NAFLD, and cardiovascular disease.

\section{Conclusion and future perspective}

There is overwhelming evidence that adipocytokines play a pivotal role in metabolic homeostasis of healthy subjects, and that deficiencies in these factors, caused by excess adiposity and adipocyte dysfunction, are a central component in the pathogenesis of the constellation of diseases surrounding obesity. Therefore, it will be fruitful to fully define the secretome of adipose tissue; novel adipocytokines identified in this process will, no doubt, provide critical insights into the functions of adipose tissue as an essential metabolic regulator. Identifying receptors for existing adipocytokines and mapping their downstream signaling pathways, especially in the context of metabolic disorders, is another area of research that could generate fresh therapeutic targets for managing adipocytokines to treat metabolic diseases. Due to the intertwined nature of metabolic and immune cells in major metabolic organs, further mechanistic

Published by Bioscientifica Ltd 
investigations are required to understand how adipocytokines integrate metabolic and inflammatory responses in each site and the pathological significance of these responses in metabolic disorders. It is particularly important to differentiate the detrimental effects of metabolic inflammation inflicted by nutritional stress and those beneficial ones underlying the physiological tissue expansion when designing anti-inflammation therapies for metabolic disorders (Ye \& McGuinness 2013). Following the example of adipocytokines, numerous muscle- and hepatocyte-secreted hormones (myokine and hepatokine) have been identified as essential metabolic regulators. Therefore, it is very likely that a comprehensive endocrine network of organ communications in nutrient sensing and metabolic homeostasis could be established in the foreseeable future. Such a blueprint of organ crosstalk would have far-reaching impact on the development of effective therapies against obesity and metabolic disease.

\section{Declaration of interest}

The author declares that there is no conflict of interest that could be perceived as prejudicing the impartiality of the review.

\section{Funding}

$\mathrm{HC}$ is funded by the Division of Intramural Research of the National Heart, Lung and Blood Institute (HL006103-02) of the NIH, USA. The author expresses his apology for not being able to cite all worthy papers owing to space limitation.

\section{References}

Abshagen K, Eipel C, Kalff JC, Menger MD \& Vollmar B 2007 Loss of NF-кB activation in Kupffer cell-depleted mice impairs liver regeneration after partial hepatectomy. American Journal of Physiology. Gastrointestinal and Liver Physiology 292 G1570-G1577. (doi:10.1152/ajpgi.00399.2006)

Aguirre V, Werner ED, Giraud J, Lee YH, Shoelson SE \& White MF 2002 Phosphorylation of Ser307 in insulin receptor substrate-1 blocks interactions with the insulin receptor and inhibits insulin action. Journal of Biological Chemistry 277 1531-1537. (doi:10.1074/ jbc.M101521200)

Al-Khalili L, Bouzakri K, Glund S, Lonnqvist F, Koistinen HA \& Krook A 2006 Signaling specificity of interleukin-6 action on glucose and lipid metabolism in skeletal muscle. Molecular Endocrinology 20 3364-3375. (doi:10.1210/me.2005-0490)

Arkan MC, Hevener AL, Greten FR, Maeda S, Li ZW, Long JM, WynshawBoris A, Poli G, Olefsky J \& Karin M 2005 IKK- $\beta$ links inflammation to obesity-induced insulin resistance. Nature Medicine 11 191-198. (doi:10.1038/nm1185)

Banerjee RR, Rangwala SM, Shapiro JS, Rich AS, Rhoades B, Qi Y, Wang J Rajala MW, Pocai A, Scherer PE et al. 2004 Regulation of fasted blood glucose by resistin. Science $\mathbf{3 0 3}$ 1195-1198. (doi:10.1126/science. 1092341)

Bastard JP, Maachi M, Van Nhieu JT, Jardel C, Bruckert E, Grimaldi A, Robert JJ, Capeau J \& Hainque B 2002 Adipose tissue IL-6 content correlates with resistance to insulin activation of glucose uptake both in vivo and in vitro. Journal of Clinical Endocrinology and Metabolism $\mathbf{8 7}$ 2084-2089. (doi:10.1210/jc.87.5.2084)

Bates SH, Stearns WH, Dundon TA, Schubert M, Tso AW, Wang Y, Banks AS, Lavery HJ, Haq AK, Maratos-Flier E et al. 2003 STAT3 signalling is required for leptin regulation of energy balance but not reproduction. Nature 421 856-859. (doi:10.1038/nature01388)

Baud V \& Karin M 2001 Signal transduction by tumor necrosis factor and its relatives. Trends in Cell Biology 11 372-377. (doi:10.1016/ S0962-8924(01)02064-5)

Baumann H, Morella KK, White DW, Dembski M, Bailon PS, Kim H, Lai CF \& Tartaglia LA 1996 The full-length leptin receptor has signaling capabilities of interleukin 6-type cytokine receptors. PNAS 93 8374-8378. (doi:10.1073/pnas.93.16.8374)

Berg AH \& Scherer PE 2005 Adipose tissue, inflammation, and cardiovascular disease. Circulation Research 96 939-949. (doi:10.1161/01.RES. 0000163635.62927 .34 )

Berg AH, Combs TP, Du X, Brownlee M \& Scherer PE 2001 The adipocytesecreted protein Acrp30 enhances hepatic insulin action. Nature Medicine 7 947-953. (doi:10.1038/90992)

Burnett MS, Lee CW, Kinnaird TD, Stabile E, Durrani S, Dullum MK, Devaney JM, Fishman C, Stamou S, Canos D et al. 2005 The potential role of resistin in atherogenesis. Atherosclerosis 182 241-248. (doi:10.1016/j.atherosclerosis.2005.02.014)

Burnett MS, Devaney JM, Adenika RJ, Lindsay R \& Howard BV 2006 Crosssectional associations of resistin, coronary heart disease, and insulin resistance. Journal of Clinical Endocrinology and Metabolism 91 64-68. (doi:10.1210/jc.2005-1653)

Cai D, Yuan M, Frantz DF, Melendez PA, Hansen L, Lee J \& Shoelson SE 2005 Local and systemic insulin resistance resulting from hepatic activation of IKK- $\beta$ and NF-кB. Nature Medicine 11 183-190. (doi:10.1038/nm1166)

Cani PD, Amar J, Iglesias MA, Poggi M, Knauf C, Bastelica D, Neyrinck AM Fava F, Tuohy KM, Chabo C et al. 2007 Metabolic endotoxemia initiates obesity and insulin resistance. Diabetes 56 1761-1772. (doi:10.2337/ db06-1491)

Cao H, Gerhold K, Mayers JR, Wiest MM, Watkins SM \& Hotamisligil GS 2008 Identification of a lipokine, a lipid hormone linking adipose tissue to systemic metabolism. Cell 134 933-944. (doi:10.1016/j.cell. 2008.07.048)

Cao H, Sekiya M, Ertunc ME, Burak MF, Mayers JR, White A, Inouye K, Rickey LM, Ercal BC, Furuhashi M et al. 2013 Adipocyte lipid chaperone AP2 is a secreted adipokine regulating hepatic glucose production. Cell Metabolism 17 768-778. (doi:10.1016/j.cmet.2013.04.012)

Carstensen M, Herder C, Kempf K, Erlund I, Martin S, Koenig W, Sundvall J, Bidel S, Kuha S, Roden M et al. 2013 Sfrp5 correlates with insulin resistance and oxidative stress. European Journal of Clinical Investigation 43 350-357. (doi:10.1111/eci.12052)

Chen BH, Song Y, Ding EL, Roberts CK, Manson JE, Rifai N, Buring JE, Gaziano JM \& Liu S 2009 Circulating levels of resistin and risk of type 2 diabetes in men and women: results from two prospective cohorts. Diabetes Care 32 329-334. (doi:10.2337/dc08-1625)

Cinti S, Mitchell G, Barbatelli G, Murano I, Ceresi E, Faloia E, Wang S, Fortier M, Greenberg AS \& Obin MS 2005 Adipocyte death defines macrophage localization and function in adipose tissue of obese mice and humans. Journal of Lipid Research 46 2347-2355. (doi:10.1194/ jlr.M500294-JLR200)

Cohen P, Miyazaki M, Socci ND, Hagge-Greenberg A, Liedtke W, Soukas AA, Sharma R, Hudgins LC, Ntambi JM \& Friedman JM 2002 Role for stearoyl-CoA desaturase-1 in leptin-mediated weight loss. Science $\mathbf{2 9 7}$ 240-243. (doi:10.1126/science.1071527)

Coppari R \& Bjorbaek C 2012 Leptin revisited: its mechanism of action and potential for treating diabetes. Nature Reviews. Drug Discovery 11 692-708. (doi:10.1038/nrd3757)

Cristancho AG \& Lazar MA 2011 Forming functional fat: a growing understanding of adipocyte differentiation. Nature Reviews. Molecular Cell Biology 12 722-734. (doi:10.1038/nrm3198) 
Dastani Z, Hivert MF, Timpson N, Perry JR, Yuan X, Scott RA, Henneman P, Heid IM, Kizer JR, Lyytikainen LP et al. 2012 Novel loci for adiponectin levels and their influence on type 2 diabetes and metabolic traits: a multi-ethnic meta-analysis of 45,891 individuals. PLoS Genetics 8 e1002607. (doi:10.1371/journal.pgen.1002607)

De Rosa V, Procaccini C, Cali G, Pirozzi G, Fontana S, Zappacosta S, La Cava A \& Matarese G 2007 A key role of leptin in the control of regulatory $\mathrm{T}$ cell proliferation. Immunity 26 241-255. (doi:10.1016/j.immuni. 2007.01.011)

Di Gregorio GB, Hensley L, Lu T, Ranganathan G \& Kern PA 2004 Lipid and carbohydrate metabolism in mice with a targeted mutation in the IL-6 gene: absence of development of age-related obesity. American Journal of Physiology. Endocrinology and Metabolism 287 E182-E187. (doi:10.1152/ ajpendo.00189.2003)

Eckel RH, Grundy SM \& Zimmet PZ 2005 The metabolic syndrome. Lancet 365 1415-1428. (doi:10.1016/S0140-6736(05)66378-7)

Emanuelli B, Peraldi P, Filloux C, Chavey C, Freidinger K, Hilton DJ, Hotamisligil GS \& Van Obberghen E 2001 SOCS-3 inhibits insulin signaling and is up-regulated in response to tumor necrosis factor- $\alpha$ in the adipose tissue of obese mice. Journal of Biological Chemistry $\mathbf{2 7 6}$ 47944-47949. (doi:10.1074/jbc.M104602200)

von Eynatten M, Lepper PM, Liu D, Lang K, Baumann M, Nawroth PP, Bierhaus A, Dugi KA, Heemann U, Allolio B et al. 2007 Retinol-binding protein 4 is associated with components of the metabolic syndrome, but not with insulin resistance, in men with type 2 diabetes or coronary artery disease. Diabetologia 50 1930-1937. (doi:10.1007/s00125-0070743-8)

Farooqi IS, Jebb SA, Langmack G, Lawrence E, Cheetham CH, Prentice AM, Hughes IA, McCamish MA \& O'Rahilly S 1999 Effects of recombinant leptin therapy in a child with congenital leptin deficiency. New England Journal of Medicine 341 879-884. (doi:10.1056/NEJM1999 09163411204)

Febbraio MA \& Pedersen BK 2002 Muscle-derived interleukin-6: mechanisms for activation and possible biological roles. FASEB Journal 16 1335-1347. (doi:10.1096/fj.01-0876rev)

Feingold KR \& Grunfeld C 1987 Tumor necrosis factor- $\alpha$ stimulates hepatic lipogenesis in the rat in vivo. Journal of Clinical Investigation 80 184-190. (doi:10.1172/JCI113046)

Fernandez-Real JM, Broch M, Vendrell J, Gutierrez C, Casamitjana R, Pugeat M, Richart C \& Ricart W 2000 Interleukin-6 gene polymorphism and insulin sensitivity. Diabetes 49 517-520. (doi:10.2337/diabetes.49. 3.517)

Feuerer M, Herrero L, Cipolletta D, Naaz A, WongJ, Nayer A, Lee J, Goldfine AB, Benoist C, Shoelson S et al. 2009 Lean, but not obese, fat is enriched for a unique population of regulatory $\mathrm{T}$ cells that affect metabolic parameters. Nature Medicine 15 930-939. (doi:10.1038/nm.2002)

Finucane MM, Stevens GA, Cowan MJ, Danaei G, Lin JK, Paciorek CJ, Singh GM, Gutierrez HR, Lu Y, Bahalim AN et al. 2011 National, regional, and global trends in body-mass index since 1980: systematic analysis of health examination surveys and epidemiological studies with 960 country-years and 9.1 million participants. Lancet 377 557-567. (doi:10.1016/S0140-6736(10)62037-5)

Friedman JM \& Halaas JL 1998 Leptin and the regulation of body weight in mammals. Nature 395 763-770. (doi:10.1038/27376)

Funahashi T, Nakamura T, Shimomura I, Maeda K, Kuriyama H, Takahashi M, Arita Y, Kihara S \& Matsuzawa Y 1999 Role of adipocytokines on the pathogenesis of atherosclerosis in visceral obesity. Internal Medicine $\mathbf{3 8}$ 202-206. (doi:10.2169/internalmedicine.38.202)

Gan L, Guo K, Cremona ML, McGraw TE, Leibel RL \& Zhang Y 2012 TNF- $\alpha$ up-regulates protein level and cell surface expression of the leptin receptor by stimulating its export via a PKC-dependent mechanism. Endocrinology 153 5821-5833. (doi:10.1210/en.2012-1510)

Gao Z, Hwang D, Bataille F, Lefevre M, York D, Quon MJ \& Ye J 2002 Serine phosphorylation of insulin receptor substrate 1 by inhibitor $\kappa \mathrm{B}$ kinase complex. Journal of Biological Chemistry 277 48115-48121. (doi:10.1074/jbc.M209459200)
Ghosh S, Singh AK, Aruna B, Mukhopadhyay S \& Ehtesham NZ 2003 The genomic organization of mouse resistin reveals major differences from the human resistin: functional implications. Gene 305 27-34. (doi:10.1016/S0378-1119(02)01213-1)

Gonzalez-Gay MA, De Matias JM, Gonzalez-Juanatey C, Garcia-Porrua C, Sanchez-Andrade A, Martin J \& Llorca J 2006 Anti-tumor necrosis factor- $\alpha$ blockade improves insulin resistance in patients with rheumatoid arthritis. Clinical and Experimental Rheumatology 24 83-86.

Gordon S 2003 Alternative activation of macrophages. Nature Reviews. Immunology 3 23-35. (doi:10.1038/nri978)

Graham TE, Yang Q, Bluher M, Hammarstedt A, Ciaraldi TP, Henry RR, Wason CJ, Oberbach A, Jansson PA, Smith U et al. 2006 Retinol-binding protein 4 and insulin resistance in lean, obese, and diabetic subjects. New England Journal of Medicine 354 2552-2563. (doi:10.1056/ NEJMoa054862)

Grunfeld C, Zhao C, Fuller J, Pollack A, Moser A, Friedman J \& Feingold KR 1996 Endotoxin and cytokines induce expression of leptin, the ob gene product, in hamsters. Journal of Clinical Investigation 97 2152-2157. (doi:10.1172/JCI118653)

Handschin C, Choi CS, Chin S, Kim S, Kawamori D, Kurpad AJ, Neubauer N, Hu J, Mootha VK, Kim YB et al. 2007 Abnormal glucose homeostasis in skeletal muscle-specific PGC- $1 \alpha$ knockout mice reveals skeletal muscle-pancreatic $\beta$ cell crosstalk. Journal of Clinical Investigation 117 3463-3474. (doi:10.1172/JCI31785)

Heidemann C, Sun Q, van Dam RM, Meigs JB, Zhang C, Tworoger SS, Mantzoros CS \& Hu FB 2008 Total and high-molecular-weight adiponectin and resistin in relation to the risk for type 2 diabetes in women. Annals of Internal Medicine 149 307-316. (doi:10.7326/ 0003-4819-149-5-200809020-00005)

Heymsfield SB, Greenberg AS, Fujioka K, Dixon RM, Kushner R, Hunt T, Lubina JA, Patane J, Self B, Hunt P et al. 1999 Recombinant leptin for weight loss in obese and lean adults: a randomized, controlled, dose-escalation trial. Journal of the American Medical Association 282 1568-1575. (doi:10.1001/jama.282.16.1568)

Hirosumi J, Tuncman G, Chang L, Gorgun CZ, Uysal KT, Maeda K, Karin M \& Hotamisligil GS 2002 A central role for JNK in obesity and insulin resistance. Nature 420 333-336. (doi:10.1038/nature01137)

Hivert MF, Sullivan LM, Fox CS, Nathan DM, D'Agostino RB Sr, Wilson PW $\&$ Meigs JB 2008 Associations of adiponectin, resistin, and tumor necrosis factor- $\alpha$ with insulin resistance. Journal of Clinical Endocrinology and Metabolism 93 3165-3172. (doi:10.1210/jc.2008-0425)

Holland WL, Miller RA, Wang ZV, Sun K, Barth BM, Bui HH, Davis KE, Bikman BT, Halberg N, Rutkowski JM et al. 2011 Receptor-mediated activation of ceramidase activity initiates the pleiotropic actions of adiponectin. Nature Medicine 17 55-63. (doi:10.1038/nm.2277)

Hotamisligil GS 2006 Inflammation and metabolic disorders. Nature 444 860-867. (doi:10.1038/nature05485)

Hotamisligil GS, Shargill NS \& Spiegelman BM 1993 Adipose expression of tumor necrosis factor- $\alpha$ : direct role in obesity-linked insulin resistance. Science 259 87-91. (doi:10.1126/science.7678183)

Hotamisligil GS, Murray DL, Choy LN \& Spiegelman BM 1994 Tumor necrosis factor $\alpha$ inhibits signaling from the insulin receptor. PNAS 91 4854-4858. (doi:10.1073/pnas.91.11.4854)

Hotamisligil GS, Johnson RS, Distel RJ, Ellis R, Papaioannou VE \& Spiegelman BM 1996 Uncoupling of obesity from insulin resistance through a targeted mutation in aP2, the adipocyte fatty acid binding protein. Science 274 1377-1379. (doi:10.1126/science.274.5291.1377)

Hu E, Liang P \& Spiegelman BM 1996 AdipoQ is a novel adipose-specific gene dysregulated in obesity. Journal of Biological Chemistry 271 10697-10703. (doi:10.1074/jbc.271.18.10697)

Hu W, Li L, Yang M, Luo X, Ran W, Liu D, Xiong Z, Liu H \& Yang G 2013 Circulating Sfrp5 is a signature of obesity-related metabolic disorders and is regulated by glucose and liraglutide in humans. Journal of Clinical Endocrinology and Metabolism 98 290-298. (doi:10.1210/jc.2012-2466)

Published by Bioscientifica Ltd 
Kamohara S, Burcelin R, Halaas JL, Friedman JM \& Charron MJ 1997 Acute stimulation of glucose metabolism in mice by leptin treatment. Nature 389 374-377. (doi:10.1038/38717)

Kazemi MR, McDonald CM, Shigenaga JK, Grunfeld C \& Feingold KR 2005 Adipocyte fatty acid-binding protein expression and lipid accumulation are increased during activation of murine macrophages by tolllike receptor agonists. Arteriosclerosis, Thrombosis, and Vascular Biology 25 1220-1224. (doi:10.1161/01.ATV.0000159163.52632.1b)

Klover PJ, Zimmers TA, Koniaris LG \& Mooney RA 2003 Chronic exposure to interleukin-6 causes hepatic insulin resistance in mice. Diabetes $\mathbf{5 2}$ 2784-2789. (doi:10.2337/diabetes.52.11.2784)

Klover PJ, Clementi AH \& Mooney RA 2005 Interleukin-6 depletion selectively improves hepatic insulin action in obesity. Endocrinology 146 3417-3427. (doi:10.1210/en.2004-1468)

Kobayashi H, Ouchi N, Kihara S, Walsh K, Kumada M, Abe Y, Funahashi T \& Matsuzawa Y 2004 Selective suppression of endothelial cell apoptosis by the high molecular weight form of adiponectin. Circulation Research 94 e27-e31. (doi:10.1161/01.RES.0000119921.86460.37)

Koh JH, Shin YG, Nam SM, Lee MY, Chung CH \& Shin JY 2009 Serum adipocyte fatty acid-binding protein levels are associated with nonalcoholic fatty liver disease in type 2 diabetic patients. Diabetes Care 32 147-152. (doi:10.2337/dc08-1379)

Kosteli A, Sugaru E, Haemmerle G, Martin JF, Lei J, Zechner R \& Ferrante AW Jr 2010 Weight loss and lipolysis promote a dynamic immune response in murine adipose tissue. Journal of Clinical Investigation 120 3466-3479. (doi:10.1172/JCI42845)

Kotnik P, Fischer-Posovszky P \& Wabitsch M 2011 RBP4: a controversial adipokine. European Journal of Endocrinology 165 703-711. (doi:10.1530/ EJE-11-0431)

Kovacs P, Geyer M, Berndt J, Kloting N, Graham TE, Bottcher Y, Enigk B, Tonjes A, Schleinitz D, Schon MR et al. 2007 Effects of genetic variation in the human retinol binding protein-4 gene (RBP4) on insulin resistance and fat depot-specific mRNA expression. Diabetes $\mathbf{5 6}$ 3095-3100. (doi:10.2337/db06-1647)

La Cava A \& Matarese G 2004 The weight of leptin in immunity. Nature Reviews. Immunology 4 371-379. (doi:10.1038/nri1350)

Lee GH, Proenca R, Montez JM, Carroll KM, Darvishzadeh JG, Lee JI \& Friedman JM 1996 Abnormal splicing of the leptin receptor in diabetic mice. Nature 379 632-635. (doi:10.1038/379632a0)

Lehrke M, Reilly MP, Millington SC, Iqbal N, Rader DJ \& Lazar MA 2004 An inflammatory cascade leading to hyperresistinemia in humans. PLoS Medicine 1 e45. (doi:10.1371/journal.pmed.0010045)

Li S, Shin HJ, Ding EL \& van Dam RM 2009 Adiponectin levels and risk of type 2 diabetes: a systematic review and meta-analysis. Journal of the American Medical Association 302 179-188. (doi:10.1001/jama. 2009.976)

Liu J, Divoux A, Sun J, Zhang J, Clement K, Glickman JN, Sukhova GK, Wolters PJ, Du J, Gorgun CZ et al. 2009 Genetic deficiency and pharmacological stabilization of mast cells reduce diet-induced obesity and diabetes in mice. Nature Medicine 15 940-945. (doi:10.1038/ nm.1994)

Lo J, Bernstein LE, Canavan B, Torriani M, Jackson MB, Ahima RS \& Grinspoon SK 2007 Effects of TNF- $\alpha$ neutralization on adipocytokines and skeletal muscle adiposity in the metabolic syndrome. American Journal of Physiology. Endocrinology and Metabolism 293 E102-E109. (doi:10.1152/ajpendo.00089.2007)

Lord GM, Matarese G, Howard JK, Baker RJ, Bloom SR \& Lechler RI 1998 Leptin modulates the T-cell immune response and reverses starvation-induced immunosuppression. Nature 394 897-901. (doi:10.1038/29795)

Lumeng CN, Bodzin JL \& Saltiel AR 2007 Obesity induces a phenotypic switch in adipose tissue macrophage polarization. Journal of Clinical Investigation 117 175-184. (doi:10.1172/JCI29881)

Ma K, Cabrero A, Saha PK, Kojima H, Li L, Chang BH, Paul A \& Chan L 2002 Increased beta-oxidation but no insulin resistance or glucose intolerance in mice lacking adiponectin. Journal of Biological Chemistry 277 34658-34661. (doi:10.1074/jbc.C200362200)
Maeda K, Okubo K, Shimomura I, Funahashi T, Matsuzawa Y \& Matsubara K 1996 cDNA cloning and expression of a novel adipose specific collagenlike factor, apM1 (adipose most abundant gene transcript 1). Biochemical and Biophysical Research Communications 221 286-289. (doi:10.1006/bbrc.1996.0587)

Maeda N, Shimomura I, Kishida K, Nishizawa H, Matsuda M, Nagaretani H, Furuyama N, Kondo H, Takahashi M, Arita Y et al. 2002 Diet-induced insulin resistance in mice lacking adiponectin/ACRP30. Nature Medicine 8 731-737. (doi:10.1038/nm724)

Maeda K, Cao H, Kono K, Gorgun CZ, Furuhashi M, Uysal KT, Cao Q, Atsumi G, Malone H, Krishnan B et al. 2005 Adipocyte/macrophage fatty acid binding proteins control integrated metabolic responses in obesity and diabetes. Cell Metabolism 1 107-119. (doi:10.1016/j.cmet. 2004.12.008)

Makowski L, Boord JB, Maeda K, Babaev VR, Uysal KT, Morgan MA, Parker RA, Suttles J, Fazio S, Hotamisligil GS et al. 2001 Lack of macrophage fatty-acid-binding protein aP2 protects mice deficient in apolipoprotein E against atherosclerosis. Nature Medicine 7 699-705. (doi:10.1038/89076)

Makowski L, Brittingham KC, Reynolds JM, Suttles J \& Hotamisligil GS 2005 The fatty acid-binding protein, aP2, coordinates macrophage cholesterol trafficking and inflammatory activity. Macrophage expression of aP2 impacts peroxisome proliferator-activated receptor gamma and I $\mathrm{KB}$ kinase activities. Journal of Biological Chemistry $\mathbf{2 8 0}$ 12888-12895. (doi:10.1074/jbc.M413788200)

Matarese G, Carrieri PB, Montella S, De Rosa V \& La Cava A 2010 Leptin as a metabolic link to multiple sclerosis. Nature Reviews. Neurology 6 455-461. (doi:10.1038/nrneurol.2010.89)

Milner KL, van der Poorten D, Xu A, Bugianesi E, Kench JG, Lam KS, Chisholm DJ \& George J 2009 Adipocyte fatty acid binding protein levels relate to inflammation and fibrosis in nonalcoholic fatty liver disease. Hepatology 49 1926-1934. (doi:10.1002/hep.22896)

Minokoshi Y, Kim YB, Peroni OD, Fryer LG, Muller C, Carling D \& Kahn BB 2002 Leptin stimulates fatty-acid oxidation by activating AMPactivated protein kinase. Nature 415 339-343. (doi:10.1038/415339a)

Mori H, Prestwich TC, Reid MA, Longo KA, Gerin I, Cawthorn WP, Susulic VS, Krishnan V, Greenfield A \& Macdougald OA 2012 Secreted frizzled-related protein 5 suppresses adipocyte mitochondrial metabolism through WNT inhibition. Journal of Clinical Investigation 122 2405-2416. (doi:10.1172/JCI63604)

Morton GJ, Gelling RW, Niswender KD, Morrison CD, Rhodes CJ \& Schwartz MW 2005 Leptin regulates insulin sensitivity via phosphatidylinositol-3-OH kinase signaling in mediobasal hypothalamic neurons. Cell Metabolism 2 411-420. (doi:10.1016/j.cmet.2005.10.009)

Munkhtulga L, Nakayama K, Utsumi N, Yanagisawa Y, Gotoh T, Omi T, Kumada M, Erdenebulgan B, Zolzaya K, Lkhagvasuren T et al. 2007 Identification of a regulatory SNP in the retinol binding protein 4 gene associated with type 2 diabetes in Mongolia. Human Genetics 120 879-888. (doi:10.1007/s00439-006-0264-4)

Nakano Y, Tobe T, Choi-Miura NH, Mazda T \& Tomita M 1996 Isolation and characterization of GBP28, a novel gelatin-binding protein purified from human plasma. Journal of Biochemistry 120 803-812. (doi:10.1093/ oxfordjournals.jbchem.a021483)

Nawrocki AR, Rajala MW, Tomas E, Pajvani UB, Saha AK, Trumbauer ME, Pang Z, Chen AS, Ruderman NB, Chen H et al. 2006 Mice lacking adiponectin show decreased hepatic insulin sensitivity and reduced responsiveness to peroxisome proliferator-activated receptor gamma agonists. Journal of Biological Chemistry 281 2654-2660. (doi:10.1074/ jbc.M505311200)

Nguyen MT, Satoh H, Favelyukis S, Babendure JL, Imamura T, Sbodio JI, Zalevsky J, Dahiyat BI, Chi NW \& Olefsky JM 2005 JNK and tumor necrosis factor- $\alpha$ mediate free fatty acid-induced insulin resistance in 3T3-L1 adipocytes. Journal of Biological Chemistry 280 35361-35371. (doi:10.1074/jbc.M504611200)

Nguyen KD, Qiu Y, Cui X, Goh YP, Mwangi J, David T, Mukundan L, Brombacher F, Locksley RM \& Chawla A 2011 Alternatively activated 
macrophages produce catecholamines to sustain adaptive thermogenesis. Nature 480 104-108. (doi:10.1038/nature10653)

Ofei F, Hurel S, Newkirk J, Sopwith M \& Taylor R 1996 Effects of an engineered human anti-TNF- $\alpha$ antibody (CDP571) on insulin sensitivity and glycemic control in patients with NIDDM. Diabetes 45 881-885. (doi:10.2337/diab.45.7.881)

Ogata A, Morishima A, Hirano T, Hishitani Y, Hagihara K, Shima Y, Narazaki M \& Tanaka T 2011 Improvement of HbA1c during treatment with humanised anti-interleukin 6 receptor antibody, tocilizumab. Annals of Rheumatic Disease 70 1164-1165. (doi:10.1136/ard.2010.132845)

Okamoto Y, Kihara S, Ouchi N, Nishida M, Arita Y, Kumada M, Ohashi K, Sakai N, Shimomura I, Kobayashi H et al. 2002 Adiponectin reduces atherosclerosis in apolipoprotein E-deficient mice. Circulation 106 2767-2770. (doi:10.1161/01.CIR.0000042707.50032.19)

Oral EA, Simha V, Ruiz E, Andewelt A, Premkumar A, Snell P, Wagner AJ DePaoli AM, Reitman ML, Taylor SI et al. 2002 Leptin-replacement therapy for lipodystrophy. New England Journal of Medicine $\mathbf{3 4 6}$ 570-578. (doi:10.1056/NEJMoa012437)

Ouchi N, Kihara S, Arita Y, Maeda K, Kuriyama H, Okamoto Y, Hotta K, Nishida M, Takahashi M, Nakamura T et al. 1999 Novel modulator for endothelial adhesion molecules: adipocyte-derived plasma protein adiponectin. Circulation 100 2473-2476. (doi:10.1161/01.CIR.100. 25.2473)

Ouchi N, Kihara S, Funahashi T, Nakamura T, Nishida M, Kumada M, Okamoto Y, Ohashi K, Nagaretani H, Kishida K et al. 2003 Reciprocal association of C-reactive protein with adiponectin in blood stream and adipose tissue. Circulation 107 671-674. (doi:10.1161/01.CIR. 0000055188.83694.B3)

Ouchi N, Higuchi A, Ohashi K, Oshima Y, Gokce N, Shibata R, Akasaki Y, Shimono A \& Walsh K 2010 Sfrp5 is an anti-inflammatory adipokine that modulates metabolic dysfunction in obesity. Science 329 454-457. (doi:10.1126/science.1188280)

Pang C, Gao Z, Yin J, Zhang J, Jia W \& Ye J 2008 Macrophage infiltration into adipose tissue may promote angiogenesis for adipose tissue remodeling in obesity. American Journal of Physiology. Endocrinology and Metabolism 295 E313-E322. (doi:10.1152/ajpendo.90296.2008)

Park EJ, Lee JH, Yu GY, He G, Ali SR, Holzer RG, Osterreicher CH, Takahashi H \& Karin M 2010 Dietary and genetic obesity promote liver inflammation and tumorigenesis by enhancing IL- 6 and TNF expression. Cell 140 197-208. (doi:10.1016/j.cell.2009.12.052)

Patel SD, Rajala MW, Rossetti L, Scherer PE \& Shapiro L 2004 Disulfidedependent multimeric assembly of resistin family hormones. Science 304 1154-1158. (doi:10.1126/science.1093466)

Petersen KF, Oral EA, Dufour S, Befroy D, Ariyan C, Yu C, Cline GW, DePaoli AM, Taylor SI, Gorden P et al. 2002 Leptin reverses insulin resistance and hepatic steatosis in patients with severe lipodystrophy. Journal of Clinical Investigation 109 1345-1350. (doi:10.1172/JCI15001)

Promintzer M, Krebs M, Todoric J, Luger A, Bischof MG, Nowotny P, Wagner O, Esterbauer H \& Anderwald C 2007 Insulin resistance is unrelated to circulating retinol binding protein and protein $\mathrm{C}$ inhibitor. Journal of Clinical Endocrinology and Metabolism 92 4306-4312. (doi:10.1210/jc.2006-2522)

Qatanani M, Szwergold NR, Greaves DR, Ahima RS \& Lazar MA 2009 Macrophage-derived human resistin exacerbates adipose tissue inflammation and insulin resistance in mice. Journal of Clinical Investigation 119 531-539. (doi:10.1172/JCI37273)

Randle PJ, Garland PB, Hales CN \& Newsholme EA 1963 The glucose fatty-acid cycle. Its role in insulin sensitivity and the metabolic disturbances of diabetes mellitus. Lancet 1 785-789. (doi:10.1016/ S0140-6736(63)91500-9)

Reilly MP, Lehrke M, Wolfe ML, Rohatgi A, Lazar MA \& Rader DJ 2005 Resistin is an inflammatory marker of atherosclerosis in humans. Circulation 111 932-939. (doi:10.1161/01.CIR.0000155620.10387.43)

Rosen ED \& Spiegelman BM 2006 Adipocytes as regulators of energy balance and glucose homeostasis. Nature $\mathbf{4 4 4} 847-853$. (doi:10.1038/ nature05483)
Rui L, Yuan M, Frantz D, Shoelson S \& White MF 2002 SOCS-1 and SOCS-3 block insulin signaling by ubiquitin-mediated degradation of IRS1 and IRS2. Journal of Biological Chemistry 277 42394-42398. (doi:10.1074/ jbc.C200444200)

Ryo M, Nakamura T, Kihara S, Kumada M, Shibazaki S, Takahashi M, Nagai M, Matsuzawa Y \& Funahashi T 2004 Adiponectin as a biomarker of the metabolic syndrome. Circulation Journal 68 975-981. (doi:10.1253/ circj.68.975)

Sabio G, Das M, Mora A, Zhang Z, Jun JY, Ko HJ, Barrett T, Kim JK \& Davis RJ 2008 A stress signaling pathway in adipose tissue regulates hepatic insulin resistance. Science 322 1539-1543. (doi:10.1126/science.1160794)

Sadagurski M, Norquay L, Farhang J, D'Aquino K, Copps K \& White MF 2010 Human IL6 enhances leptin action in mice. Diabetologia 53 525-535. (doi:10.1007/s00125-009-1580-8)

Samuel VT, Petersen KF \& Shulman GI 2010 Lipid-induced insulin resistance: unravelling the mechanism. Lancet 375 2267-2277. (doi:10.1016/S0140-6736(10)60408-4)

Scherer PE, Williams S, Fogliano M, Baldini G \& Lodish HF 1995 A novel serum protein similar to $\mathrm{C} 1 \mathrm{q}$, produced exclusively in adipocytes. Journal of Biological Chemistry 270 26746-26749. (doi:10.1074/jbc.270. 45.26746)

Schultz O, Oberhauser F, Saech J, Rubbert-Roth A, Hahn M, Krone W \& Laudes M 2010 Effects of inhibition of interleukin-6 signalling on insulin sensitivity and lipoprotein (a) levels in human subjects with rheumatoid diseases. PLOS ONE 5 e14328. (doi:10.1371/journal.pone. 0014328)

Shibata R, Sato K, Pimentel DR, Takemura Y, Kihara S, Ohashi K, Funahashi T, Ouchi N \& Walsh K 2005 Adiponectin protects against myocardial ischemia-reperfusion injury through AMPK- and COX-2-dependent mechanisms. Nature Medicine 11 1096-1103. (doi:10.1038/nm1295)

Shum BO, Mackay CR, Gorgun CZ, Frost MJ, Kumar RK, Hotamisligil GS \& Rolph MS 2006 The adipocyte fatty acid-binding protein aP2 is required in allergic airway inflammation. Journal of Clinical Investigation $\mathbf{1 1 6}$ 2183-2192. (doi:10.1172/JCI24767)

Simon I, Escote X, Vilarrasa N, Gomez J, Fernandez-Real JM, Megia A, Gutierrez C, Gallart L, Masdevall C \& Vendrell J 2009 Adipocyte fatty acid-binding protein as a determinant of insulin sensitivity in morbidobese women. Obesity 17 1124-1128.

Spranger J, Kroke A, Mohlig M, Hoffmann K, Bergmann MM, Ristow M, Boeing H \& Pfeiffer AF 2003 Inflammatory cytokines and the risk to develop type 2 diabetes: results of the prospective population-based European Prospective Investigation into Cancer and Nutrition (EPIC)Potsdam Study. Diabetes 52 812-817. (doi:10.2337/diabetes.52.3.812)

Stejskal D \& Karpisek M 2006 Adipocyte fatty acid binding protein in a Caucasian population: a new marker of metabolic syndrome? European Journal of Clinical Investigation 36 621-625. (doi:10.1111/j.1365-2362. 2006.01696.x)

Stephens JW, Hurel SJ, Lowe GD, Rumley A \& Humphries SE 2007 Association between plasma IL-6, the IL6 -174G $>$ C gene variant and the metabolic syndrome in type 2 diabetes mellitus. Molecular Genetics and Metabolism 90 422-428. (doi:10.1016/j.ymgme.2006.10.004)

Steppan CM, Bailey ST, Bhat S, Brown EJ, Banerjee RR, Wright CM, Patel HR, Ahima RS \& Lazar MA 2001 The hormone resistin links obesity to diabetes. Nature 409 307-312. (doi:10.1038/35053000)

St-Pierre J \& Tremblay ML 2012 Modulation of leptin resistance by protein tyrosine phosphatases. Cell Metabolism 15 292-297. (doi:10.1016/ j.cmet.2012.02.004)

Strissel KJ, Stancheva Z, Miyoshi H, Perfield JW II, DeFuria J, Jick Z, Greenberg AS \& Obin MS 2007 Adipocyte death, adipose tissue remodeling, and obesity complications. Diabetes 56 2910-2918. (doi:10.2337/db07-0767)

Takemura Y, Ouchi N, Shibata R, Aprahamian T, Kirber MT, Summer RS, Kihara S \& Walsh K 2007 Adiponectin modulates inflammatory reactions via calreticulin receptor-dependent clearance of early apoptotic bodies. Journal of Clinical Investigation 117 375-386. (doi:10.1172/JCI29709) 
Trujillo ME \& Scherer PE 2006 Adipose tissue-derived factors: impact on health and disease. Endocrine Reviews 27 762-778. (doi:10.1210/ er.2006-0033)

Uysal KT, Wiesbrock SM, Marino MW \& Hotamisligil GS 1997 Protection from obesity-induced insulin resistance in mice lacking TNF- $\alpha$ function. Nature 389 610-614. (doi:10.1038/39335)

Uysal KT, Wiesbrock SM \& Hotamisligil GS 1998 Functional analysis of tumor necrosis factor (TNF) receptors in TNF- $\alpha$-mediated insulin resistance in genetic obesity. Endocrinology 139 4832-4838. (doi:10.1210/en.139.12.4832)

Vozarova B, Weyer C, Hanson K, Tataranni PA, Bogardus C \& Pratley RE 2001 Circulating interleukin-6 in relation to adiposity, insulin action, and insulin secretion. Obesity Research 9 414-417. (doi:10.1038/oby.2001.54)

Wallenius V, Wallenius K, Ahren B, Rudling M, Carlsten H, Dickson SL, Ohlsson C \& Jansson JO 2002 Interleukin-6-deficient mice develop mature-onset obesity. Nature Medicine 8 75-79. (doi:10.1038/nm0102-75)

Wang S, Soni KG, Semache M, Casavant S, Fortier M, Pan L \& Mitchell GA 2008 Lipolysis and the integrated physiology of lipid energy metabolism. Molecular Genetics and Metabolism 95 117-126. (doi:10.1016/j.ymgme.2008.06.012)

Weisberg SP, McCann D, Desai M, Rosenbaum M, Leibel RL \& Ferrante AW Jr 2003 Obesity is associated with macrophage accumulation in adipose tissue. Journal of Clinical Investigation 112 1796-1808. (doi:10.1172/ JCI19246)

Winer S, Chan Y, Paltser G, Truong D, Tsui H, Bahrami J, Dorfman R, Wang Y, Zielenski J, Mastronardi F et al. 2009 Normalization of obesity-associated insulin resistance through immunotherapy. Nature Medicine 15 921-929. (doi:10.1038/nm.2001)

Wu D, Molofsky AB, Liang HE, Ricardo-Gonzalez RR, Jouihan HA, Bando JK, Chawla A \& Locksley RM 2011 Eosinophils sustain adipose alternatively activated macrophages associated with glucose homeostasis. Science $\mathbf{3 3 2}$ 243-247. (doi:10.1126/science.1201475)

Xu A, Wang Y, Keshaw H, Xu LY, Lam KS \& Cooper GJ 2003a The fatderived hormone adiponectin alleviates alcoholic and nonalcoholic fatty liver diseases in mice. Journal of Clinical Investigation 112 91-100. (doi:10.1172/JCI17797)

Xu H, Barnes GT, Yang Q, Tan G, Yang D, Chou CJ, Sole J, Nichols A, Ross JS, Tartaglia LA et al. $2003 b$ Chronic inflammation in fat plays a crucial role in the development of obesity-related insulin resistance. Journal of Clinical Investigation 112 1821-1830. (doi:10.1172/JCI19451)

Xu A, Wang Y, Xu JY, Stejskal D, Tam S, Zhang J, Wat NM, Wong WK \& Lam KS 2006 Adipocyte fatty acid-binding protein is a plasma biomarker closely associated with obesity and metabolic syndrome. Clinical Chemistry 52 405-413. (doi:10.1373/clinchem.2005.062463)

Yamauchi T \& Kadowaki T 2008 Physiological and pathophysiological roles of adiponectin and adiponectin receptors in the integrated regulation of metabolic and cardiovascular diseases. International Journal of Obesity 32(Suppl 7) S13-S18. (doi:10.1038/ijo.2008.233)
Yamauchi T, Kamon J, Waki H, Terauchi Y, Kubota N, Hara K, Mori Y, Ide T, Murakami K, Tsuboyama-Kasaoka N et al. 2001 The fat-derived hormone adiponectin reverses insulin resistance associated with both lipoatrophy and obesity. Nature Medicine 7 941-946. (doi:10.1038/90984)

Yamauchi T, Kamon J, Minokoshi Y, Ito Y, Waki H, Uchida S, Yamashita S, Noda M, Kita S, Ueki K et al. 2002 Adiponectin stimulates glucose utilization and fatty-acid oxidation by activating AMP-activated protein kinase. Nature Medicine 8 1288-1295. (doi:10.1038/nm788)

Yamauchi T, Kamon J, Ito Y, Tsuchida A, Yokomizo T, Kita S, Sugiyama T, Miyagishi M, Hara K, Tsunoda M et al. 2003 Cloning of adiponectin receptors that mediate antidiabetic metabolic effects. Nature $\mathbf{4 2 3}$ 762-769. (doi:10.1038/nature01705)

Yamauchi T, Nio Y, Maki T, Kobayashi M, Takazawa T, Iwabu M, Okada-Iwabu M, Kawamoto S, Kubota N, Kubota T et al. 2007 Targeted disruption of AdipoR1 and AdipoR2 causes abrogation of adiponectin binding and metabolic actions. Nature Medicine 13 332-339. (doi:10.1038/nm1557)

Yang Q, Graham TE, Mody N, Preitner F, Peroni OD, Zabolotny JM, Kotani K, Quadro L \& Kahn BB 2005 Serum retinol binding protein 4 contributes to insulin resistance in obesity and type 2 diabetes. Nature 436 356-362. (doi:10.1038/nature03711)

Yao-Borengasser A, Varma V, Bodles AM, Rasouli N, Phanavanh B, Lee MJ, Starks T, Kern LM, Spencer HJ III, Rashidi AA et al. 2007 Retinol binding protein 4 expression in humans: relationship to insulin resistance, inflammation, and response to pioglitazone. Journal of Clinical Endocrinology and Metabolism 92 2590-2597. (doi:10.1210/ jc.2006-0816)

Ye J \& Keller JN 2010 Regulation of energy metabolism by inflammation: a feedback response in obesity and calorie restriction. Aging 2 361-368.

Ye J \& McGuinness OP 2013 Inflammation during obesity is not all bad: evidence from animal and human studies. American Journal of Physiology. Endocrinology and Metabolism 304 E466-E477. (doi:10.1152/ ajpendo.00266.2012)

Yeung DC, Xu A, Cheung CW, Wat NM, Yau MH, Fong CH, Chau MT \& Lam KS 2007 Serum adipocyte fatty acid-binding protein levels were independently associated with carotid atherosclerosis. Arteriosclerosis, Thrombosis, and Vascular Biology 27 1796-1802. (doi:10.1161/ATVBAHA.107.146274)

Yuan M, Konstantopoulos N, Lee J, Hansen L, Li ZW, Karin M \& Shoelson SE 2001 Reversal of obesity- and diet-induced insulin resistance with salicylates or targeted disruption of Ikk $\beta$. Science 293 1673-1677. (doi:10.1126/science.1061620)

Zhang Y, Proenca R, Maffei M, Barone M, Leopold L \& Friedman JM 1994 Positional cloning of the mouse obese gene and its human homologue. Nature 372 425-432. (doi:10.1038/372425a0)

Zhang X, Zhang G, Zhang H, Karin M, Bai H \& Cai D 2008 Hypothalamic IKK $\beta / N F-\kappa B$ and ER stress link overnutrition to energy imbalance and obesity. Cell 135 61-73. (doi:10.1016/j.cell.2008.07.043)

Received in final form 30 October 2013

Accepted 7 November 2013 http://joe.endocrinology-journals.org

DOI: 10.1530/JOE-13-0339
C 2014 Society for Endocrinology Printed in Great Britain
Published by Bioscientifica Ltd 